\title{
Don't ask, don't tell: patterns of HIV disclosure among HIV positive men who have sex with men with recent STI practising high risk behaviour in Los Angeles and Seattle
}

\author{
P M Gorbach, J T Galea, B Amani, A Shin, C Celum, P Kerndt, M R Golden
}

Sex Transm Infect 2004;80:512-517. doi: 10.1136/sti.2004.010918

See end of article for authors' affiliations

Correspondence to: Pamina Gorbach, MHS DrPH, Department of Epidemiology, School of Public Health, Box 951772, University of California Los Angeles, Los Angeles, CA $900095-$ 1772, USA; pgorbach@ ucla.edu

Accepted for publication 21 July 2004

\begin{abstract}
Objectives: A high incidence of HIV continues among men who have sex with men (MSM) in industrialised nations and research indicates many MSM do not disclose their HIV status to sex partners. Themes as to why MSM attending sexually transmitted infection (STI) clinics in Los Angeles and Seattle do and do not disclose their HIV status are identified.

Methods: 55 HIV positive MSM (24 in Seattle, 31 in Los Angeles) reporting recent STI or unprotected anal intercourse with a serostatus negative or unknown partner from STI clinics underwent in-depth interviews about their disclosure practices that were tape recorded, transcribed verbatim, coded, and content analysed.

Results: HIV disclosure themes fell into a continuum from unlikely to likely. Themes for "unlikely to disclose" were HIV is "nobody's business," being in denial, having a low viral load, fear of rejection, "it's just sex," using drugs, and sex in public places. Themes for "possible disclosure" were type of sex practised and partners asking/disclosing first. Themes for "likely to disclose" were feelings for partner, feeling responsible for partner's health, and fearing arrest. Many reported non-verbal disclosure methods. Some thought partners should ask for HIV status; many assumed if not asked then their partner must be positive. Conclusions: HIV positive MSM's decision to disclose their HIV status to sex partners is complex, and is influenced by a sense of responsibility to partners, acceptance of being HIV positive, the perceived transmission risk, and the context and meaning of sex. Efforts to promote disclosure will need to address these complex issues.
\end{abstract}

$\mathrm{R}$ ates of sexually transmitted infections (STI) have been rising and high risk sexual behaviour is increasing among men who have sex with men (MSM) along the west coast of the United States. ${ }^{12}$ Risky behaviours also continue to be practised by many HIV positive MSM. ${ }^{3}$ Recent CDC HIV prevention initiatives ${ }^{4}$ and guidelines ${ }^{5}$ propose a new emphasis on HIV prevention among people already known to be HIV positive. Among other things, these initiatives and guidelines advocate that public health programmes encourage people with HIV to disclose (we define "disclosure" as verbally revealing one's HIV positive status to a prospective sexual partner before engaging in sexual acts) their HIV status to sex partners. ${ }^{6}$ Yet among HIV positive MSM reporting unprotected sex, $42 \%^{3}$ to $48 \%{ }^{7}$ report not disclosing their HIV status to prospective sex partners before having unprotected sex. In the absence of such information, HIV negative men lack the ability to make fully informed choices about their level of risk.

Previous research on HIV disclosure among MSM has associated increased disclosure with a sense of responsibility for preventing transmission ${ }^{8}$ and a lower likelihood of disclosure with substance use, ${ }^{9}$ fear of rejection, ${ }^{10}$ and casual partnerships. ${ }^{11}$ Most of these studies were among MSM recruited from community or HIV care settings; to date, disclosure has not been qualitatively studied among HIV positive MSM with STI. Since STI clinics are a point of contact with the public health system, they may constitute a venue more amenable to the incorporation of public health interventions. Moreover, patients in such clinics frequently present with symptomatic STIs and may therefore be particularly important in ongoing HIV transmission. ${ }^{12}{ }^{13}$

In order to identify barriers to HIV disclosure in this population, we conducted an ethnographic study among HIV positive MSM seeking treatment for STI in two STI clinics in major west coast cities, Los Angeles and Seattle, to identify why these men have unprotected sex without disclosing their HIV status to their partners. The purpose was to identify barriers to HIV disclosure that might be amenable to interventions at STI clinics among men at high risk for transmitting HIV to others.

\section{STUDY DESIGN}

From April 2002 through August 2003 we interviewed 55 MSM recruited from STI clinics in Seattle and Los Angeles (24 in Seattle and 31 in Los Angeles) reporting transmission risk defined as having either a recent STI (gonorrhoea, chlamydial infection, or syphilis) or recent unprotected anal intercourse (UAI) with an HIV negative or serostatus unknown partner. Participants underwent in-depth interviews that were tape recorded, transcribed verbatim, coded, and content analysed for themes.

Three male interviewers underwent special training in ethnographic techniques including probing, framing, summarising, and checking. ${ }^{14}$ The interviewers followed a set of questions regarding potential interventions for HIV positive MSM of which disclosure of HIV status was one part of the interview (table 1).

\section{DATA ANALYSES}

Data from both cities were entered into Ethnograph v 5.0 (Scolari, Thousand Oaks, CA, USA), a computer program for textual and content analysis. After constructing a codebook, the response text was searched, labelled, extracted, and

Abbreviations: MSM, men who have sex with men; STI, sexually transmitted infections; UAl, unprotected anal intercourse 
Table 1 Did you tell your last sexual partner, with whom you had unprotected anal intercourse, your HIV status?

If yes-did disclose HIV status:

- When did you discuss it, before or after you first had sex?

If disclosed before having unprotected sex:

- Because you told him before you had sex, did you feel it was OK for him to have unprotected sex with you? Why? Why not?

If disclosed after having unprotected sex:

- Why do you think the two of you didn't discuss HIV before sex?

- If you only discussed HIV after you had unprotected sex, did that change what you did together next (or what else you did)?

If no-did not disclose HIV status:

- Why didn't you disclose?

- How usual is it for you to not disclose? How was this time different?

- Did the two of you talk about viral load or HIV medications?

- How did viral load or HIV medications influence what you did?

- What would have made it easier to tell him?

categorised for references to disclosure habits. Interview segments with the same code were then grouped and analysed for similarities and differences. ${ }^{15}$ Two individuals independently coded the interviews and discrepancies were compared and discussed with the investigators to establish a coding system reproducible between coders and to standardise code definitions so that intercoder concordance could be assessed. Matrices were developed for each of the codes to note common threads and contrasts found in the statements. ${ }^{16}$

Participants received an anonymous study code; no personal identifiers were collected. The human subjects committees at the University of Washington, the University of California, Los Angeles, and the Los Angeles Gay and Lesbian Center approved the protocol. All participants gave informed consent and received financial compensation for participation.

\section{RESULTS}

There was a large range in age of respondents (24-52 years) with a mean age of 38.5 years. The mean years since HIV diagnosis was 9 years in Los Angeles and 6 years in Seattle, with only one third and one half diagnosed in the past 5 years in Los Angeles and Seattle, respectively. The men interviewed differed by ethnicity and educational status between the two cities. Most interviewed in Los Angeles $(67 \%)$ and one third in Seattle were ethnic minority men while most (79\%) in Seattle but only 38\% in Los Angeles had greater than a high school education (table 2 ).

Of the 55 HIV positive MSM interviewed, only $16 \%$ had a consistent pattern of disclosure: two men said they never disclosed and seven men said they always disclosed their HIV status to sex partners. Themes for disclosure (or not) were generally found across both cities. The disclosure themes identified were HIV is nobody's business, in denial, low viral load, rejection fear, drug use, just sex, public place, type of sex, partner asks or discloses first, feelings for partner, responsibility, and fear of arrest/jail. Verbatim quotes that represent the patterns described are presented in table 3 and are referred to in each section below. Themes from the interview content analysis showed that HIV status disclosure followed a continuum of likelihood to disclose (fig 1), and that the likelihood of disclosure occurring was based on multiple and often competing factors. Finally, some men indicated that they employed indirect (that is, non-verbal) means to disclose their HIV status.

\section{Nobody's business}

One of the themes at the end of the continuum, where disclosure was very unlikely, was that one's HIV status is "nobody's business." It was felt that because HIV is a disease, it is perceived to be personal information about a "medical condition" (quote 1) or simply private information that no one else needs to know (quote 2).

\section{In denial}

Some respondents clearly articulated that they were unlikely to disclose their HIV status because they didn't want to think about being HIV positive and were in denial about their status to themselves as well as to others. While this was sometimes reported as related to a concern with the effect this would have on their image if their HIV status were known, as expressed by a man in Los Angeles (quote 3), others expressed a more general concern about not wanting to confront their own status.

\section{Low viral load}

Low viral load and perceptions of lower infectiousness were reported only by Seattle men as a reason for being unlikely to disclose their status. These men perceived themselves as unlikely to transmit HIV, consequently removing what they felt was a need to disclose. Interestingly, a few of these men also expressed a belief that low transmissibility may not be associated with low viral load, as expressed by a man from Seattle (quote 4) - a contradiction in his rationale. Another man, also from Seattle (quote 5), said he had a "false sense of security" from having a low viral load, using this to explain why he did not need to disclose but also recognising that this was not a foolproof rationale.

\begin{tabular}{|c|c|c|c|}
\hline & Seattle $(n=24)$ & Los Angeles $(n=31$ ) & Combined $(n=55)$ \\
\hline $\begin{array}{l}\text { Mean age (range) } \\
\text { Race/ethnicity }\end{array}$ & $39(30-52)$ & $38(24-48)$ & $38.5(4-52)$ \\
\hline White & 17 (71\%) & $10(32 \%)$ & $27(49 \%)$ \\
\hline African American & $4(17 \%)$ & $16(52 \%)$ & $20(36 \%)$ \\
\hline Hispanic/Latino & $1(4 \%)$ & $4(13 \%)$ & $5(9 \%)$ \\
\hline Asian & $2(8 \%)$ & $0(0 \%)$ & $2(4 \%)$ \\
\hline Other & $0(0 \%)$ & $1(3 \%)$ & $1(2 \%)$ \\
\hline $\begin{array}{l}\text { Mean years since diagnosed with HIV } \\
\text { Education - highest level reached }\end{array}$ & 6 & 9 & 7.5 \\
\hline$<$ High school & $1(4 \%)$ & $3(10 \%)$ & $4(7 \%)$ \\
\hline High school & $4(17 \%)$ & $16(52 \%)$ & $20(36 \%)$ \\
\hline Trade & $12(50 \%)$ & $5(16 \%)$ & $17(31 \%)$ \\
\hline College (BA) & $4(17 \%)$ & $6(19 \%)$ & 10 (18\%) \\
\hline $\mathrm{MA} / \mathrm{PhD}$ & $3(12 \%)$ & $1(3 \%)$ & $4(8 \%)$ \\
\hline
\end{tabular}




\begin{tabular}{|c|c|c|c|c|}
\hline \multirow[t]{2}{*}{$\begin{array}{c}\text { Disclosure much less } \\
\text { likely }\end{array}$} & \multicolumn{2}{|c|}{ Sometimes disclosure } & \multicolumn{2}{|c|}{$\begin{array}{c}\text { Disclosure much more } \\
\text { likely }\end{array}$} \\
\hline & & Themes & \multirow{5}{*}{$\begin{array}{l}\text { Feelings for partner/ } \\
\text { more than "just sex" } \\
\text { Feels responsibility to } \\
\text { prevent transmission }\end{array}$} & \multirow{4}{*}{$\begin{array}{l}\text { Fears } \\
\text { arrest/jail }\end{array}$} \\
\hline \multirow{4}{*}{$\begin{array}{l}\text { Nobody's business } \\
\text { In denial } \\
\text { Low viral load }\end{array}$} & $\begin{array}{l}\text { Fears } \\
\text { rejection }\end{array}$ & Type of sex & & \\
\hline & Just sex & Partner asks & & \\
\hline & Drug use & $\begin{array}{l}\text { Partner discloses } \\
\text { first }\end{array}$ & & \\
\hline & Public pla & & & \\
\hline
\end{tabular}

Figure 1 Continuum of likelihood of disclosure based on representative themes.

\section{Fear of rejection}

Some men expressed a fear of being rejected by a prospective partner as a reason that they only disclosed sometimes; this theme fell close to the middle of the continuum of likelihood to disclose. In addition, some men were more concerned about the possibility of rejection when they felt that a prospective partner was particularly desirable (quote 6). Other men had an overall fear of people not being willing to have sex with them (quote 7) or being treated differently"wrapped in saran wrap" —as expressed by a man from Los Angeles (quote 8).

\section{Just sex}

Many men expressed that if they were having casual sex with no interest in an ongoing relationship then they were unlikely to disclose. There was less sense of an obligation to disclose to those who were viewed only as sex partners (quotes 9,10 ).

\section{Drug use}

Men mentioned drug use as a reason for not disclosing, with the most common drug implicated being methamphetamines ("crystal meth"). Some men stated that it made them forget a need to disclose because they were "exhilarated" (quote 11), others said it "impaired judgment" so all they thought about was sex (quote 12), and others expressed a sense that disclosure would get in the way of sex and the drugs made them not want anything to get in the way (quote 13).

\section{Public place}

Some men mentioned that physical location impacted their decision to disclose. Public places were often mentioned as places where it was difficult or inappropriate to disclose one's status. Some men mentioned bathhouses (quote 14), parks (quote 14, 15), and bars (quote 16) as locales where disclosure was unlikely. Reasons for the inappropriateness of disclosure in these places varied from there being too many other people around and therefore a lack of privacy-for example, in a park (quote 15) to being in a place that is supposed to be "social" like a bar (quote 16) and disclosure not "belonging" in that environment.

\section{Type of sex}

Given the type of sexual activity engaged in, some men did not disclose if they thought there was little risk involved. This included using a condom (quote 17), not having anal sex (quote 18), having only receptive anal sex (quote 19), or having only oral sex (quotes 20, 21). With condoms, men expressed feeling that they were adequately protecting their partner, thereby eliminating the need to disclose their status.

\section{Partner asks or discloses first}

Another theme was whether a partner initiated a discussion of serostatus or disclosed first. Disclosure was more likely to happen, but not guaranteed, when a sex partner directly asked for the participant's HIV status (quotes 22, 23) or disclosed his HIV status first (quotes 24, 25). Additionally, some participants reported that first hearing that their partner was HIV positive made it more likely for them to in turn disclose their HIV positive status or, conversely, withhold their HIV status if their partner did not say first that he was HIV positive (quote 24). No man mentioned disclosing after a partner told him he was HIV negative. In fact, one man stated that he withheld his HIV status because the partner didn't say he was HIV positive (quote 24). Some MSM stated clearly that they thought partners should ask for HIV status, and if they did not ask, they could assume the partner must be positive.

\section{Feelings for partner}

Men stated they were much more likely to disclose their status in situations where they had feelings for a partner. In particular, when having sex with a partner with whom they hoped to establish a relationship, disclosure was seen as a necessary first step (quote 26). Men expressed disclosure as part of establishing an "emotional bond" (quote 27) and as feeling like someone they cared about had a "right to know" (quote 28). While men often expressed apprehension about disclosing in these dating or relationship scenarios, they also mentioned disclosure as an expectation and a requirement for a relationship to progress.

\section{Responsibility}

A sense of responsibility about HIV transmission was related to a much greater likelihood of HIV disclosure to partners. Some felt it was "not fair" to not disclose (quote 29), while others felt concerned about "spreading" HIV and the seriousness of this; that it could be "killing people" (quote $30)$.

\section{Fear of arrest}

The final theme around disclosure was also expressed by men who reported always disclosing. This was a fear of being arrested or legally prosecuted for not disclosing and was expressed by more men in Los Angeles than Seattle. Two men mentioned that non-disclosure could be considered "murder" or "manslaughter" (quotes 32, 34) while another thought it was a "felony rap" (quote 33). A strong desire to avoid prison motivated these men to always disclose, while for others, just knowing that disclosure was a legal issue made them feel like "you have to" disclose (quote 31 ). 
Table 3 Representative quotes by theme

\begin{tabular}{|c|c|c|c|}
\hline Theme & Representative quote & Age & Ethnicity \\
\hline \multirow[t]{2}{*}{ It's nobody's business } & $\begin{array}{l}\text { (1) "This is a medical condition that I've got and why should I tell everybody?" } \\
\text { (Seattle) }\end{array}$ & 43 & W \\
\hline & (2) "...it was nobody's business but mine." (Los Angeles) & 27 & AA \\
\hline In denial & $\begin{array}{l}\text { (3) "Me in denial about the status, me not want nobody to know. Ruin me image." } \\
\text { (Los Angeles) }\end{array}$ & 44 & AA \\
\hline \multirow[t]{2}{*}{ Low viral load } & $\begin{array}{l}\text { (4) "I get regular blood work done, monitor my viral loads, and things of that sort...I } \\
\text { know it isn't entirely true, but I tend to think that if your viral load is low, and your } \\
\text { immune system is strong, that you probably have less of the virus forcing through } \\
\text { your body." (Seattle) }\end{array}$ & 40 & W \\
\hline & $\begin{array}{l}\text { (5) "There was no conversation and I ended up fucking him-again, the false sense } \\
\text { of security that my viral load is zero. I don't feel too bad about it." (Seattle) }\end{array}$ & 49 & AS \\
\hline \multirow[t]{3}{*}{ Fear of rejection } & $\begin{array}{l}\text { (6) "Some guys I talk to, they're like, this guy was so hot I wasn't going to talk about } \\
\text { anything because I didn't want to blow my chance to have sex with him." (Seattle) }\end{array}$ & 41 & W \\
\hline & $\begin{array}{l}\text { (7) "I just... sometimes it don't always pay to be-to tell people-because a lot of } \\
\text { times it just runs them off, you know...?" (Los Angeles) }\end{array}$ & 42 & W \\
\hline & $\begin{array}{l}\text { (8) "I feel like you've treated me like I should be wrapped in saran warp from head to } \\
\text { toe." (Los Angeles) }\end{array}$ & 39 & W \\
\hline \multirow[t]{2}{*}{ Just sex } & $\begin{array}{l}\text { (9) "I feel like it wasn't even important because I don't really know him and he } \\
\text { doesn't really me. And all it's about... is just a sexual thing." (Los Angeles) }\end{array}$ & 41 & $\mathrm{AA}$ \\
\hline & $\begin{array}{l}\text { (10) "...if I'm never going to see them again and it's a casual experience, I'm not } \\
\text { necessarily interested in going down that road [disclosure]" (Seattle) }\end{array}$ & 35 & W \\
\hline \multirow[t]{3}{*}{ Drug use } & $\begin{array}{l}\text { (11) "I guess the effect of the crystal was just so exhilarating, I guess, it didn't even } \\
\text { enter my mind to even say anything." (Los Angeles) }\end{array}$ & 34 & W \\
\hline & $\begin{array}{l}\text { (12) "The crystal meth impaired my judgment, and all I could care about was just } \\
\text { getting laid, you know." (Los Angeles) }\end{array}$ & 40 & $\mathrm{H}$ \\
\hline & $\begin{array}{l}\text { (13) "In the heat of the moment, the drugs, you know, wanting to have sex....that's } \\
\text { it." [...] I mean, you're-you're-you're up there, and you like, hey, I got to have me } \\
\text { some sex. And I'm going to do anything to get it." (Los Angeles) }\end{array}$ & 35 & W \\
\hline \multirow[t]{3}{*}{ Public place } & $\begin{array}{l}\text { (14) "Total anonymity in a bathhouse or the park, you're not going, 'oh, before you } \\
\text { put your mouth there you should know [that I'm positive]." (Seatlle) }\end{array}$ & 40 & W \\
\hline & $\begin{array}{l}\text { (15) "...there were of other people standing around [at the park]...the } \\
\text { environment... it just didn't seem aporopriate, I guess." (Los Angeles) }\end{array}$ & 22 & $\mathrm{H}$ \\
\hline & $\begin{array}{l}\text { (16) "... a bar, it's more like a social place, and it, they're here, they're to have, } \\
\text { supposed to have fun, dance drink whatever, and to bring that up, it would, it would } \\
\text { probably kinda, awfully, turn off the other person." (Los Angeles) }\end{array}$ & 47 & $\mathrm{AA}$ \\
\hline \multicolumn{4}{|c|}{ prodady Kinad, awionly, Iurn oir me oiner person. (Los Anigeles) } \\
\hline Partner wants to use a condom & $\begin{array}{l}\text { (17) "No, I didn't tell him my status, because he wanted to use a condom, so I figured } \\
\text { why tell him, if he always want, if he wants to use a condom so why tell him?" (Los } \\
\text { Angeles) }\end{array}$ & 40 & AA \\
\hline No anal sex & $\begin{array}{l}\text { (18) "I mean I knew I wasn't going to take off all my clothes and, and have... anal sex } \\
\text { with him, so, I was just like you know I kept my mouth shut and, and then do what I } \\
\text { have to do, and that was that." (Los Angeles) }\end{array}$ & 27 & AA \\
\hline Only receptive anal sex & $\begin{array}{l}\text { (19) "Being the receptive anal partner, probably less infective, less of a concern." } \\
\text { (Seattle) }\end{array}$ & 49 & $\mathrm{Al}$ \\
\hline \multirow[t]{2}{*}{ Gave oral sex } & $\begin{array}{l}\text { (20) "...it was just um one of those things where, you know, I gave somebody oral } \\
\text { sex, and, and... just didn't feel it was necessary because of the low risk, or whatever, } \\
\text { of HIV." (Los Angeles) }\end{array}$ & 39 & $\mathrm{H}$ \\
\hline & $\begin{array}{l}\text { (21) "If I'm only giving him head and we're kissing, there's no need to tell him." } \\
\text { (Seattle) }\end{array}$ & 38 & W \\
\hline \multirow[t]{4}{*}{ Partner asks or discloses first } & (22) "If they were to ask me straight out, I would tell them straight out." (Seattle) & 41 & W \\
\hline & (23) "I d disclosed] because he asked." (Seattle) & 52 & W \\
\hline & $\begin{array}{l}\text { (24) "If they would've told me they were HIV then I would've felt more comfortable, } \\
\text { and told them I was." }\end{array}$ & 39 & W \\
\hline & (25) Yes, [I told him I was HIV positive] because he told me that he was positive too." & 27 & AA \\
\hline \multirow[t]{3}{*}{ Feelings for partner } & $\begin{array}{l}\text { (26) "He was a really sweet guy. It was like, OK, this could be a lot of fun. Who } \\
\text { knows? This could lead somewhere. I am going to let him know." (Seatlle) }\end{array}$ & 51 & W \\
\hline & $\begin{array}{l}\text { (27) "... If you make a bond on an emotional level, I certainly feel more obligated to } \\
\text { divulge my status because I might want to continue a relationship with them." } \\
\text { (Seattle) }\end{array}$ & 35 & W \\
\hline & $\begin{array}{l}\text { (28) "Well the reason because I wanted him to be in my life and I felt that he had a } \\
\text { right to know." (Los Angeles) }\end{array}$ & 45 & $\mathrm{AA}$ \\
\hline \multirow[t]{2}{*}{ Responsibility } & $\begin{array}{l}\text { (29) "I don't think it's fair and I think they should have an option to have sex or not to } \\
\text { have sex...don't want to ruin his life and, you know..." (Los Angeles) }\end{array}$ & 45 & AA \\
\hline & $\begin{array}{l}\text { (30) It's not like something you want to spread around... it's like killing people." (Los } \\
\text { Angeles) }\end{array}$ & 33 & W \\
\hline \multirow[t]{4}{*}{ Fear of arrest } & (31) "There is a legal issue. You have to." (Seattle) & 44 & W \\
\hline & $\begin{array}{l}\text { (32) "I heard stories about you can go to jail for like attempted murder and I don't } \\
\text { want to have to go through that. I'm } 46 \text { years old and what little time I have left on } \\
\text { this earth, I would like to enjoy it outside of a jail." (Los Angeles) }\end{array}$ & 47 & AA \\
\hline & $\begin{array}{l}\text { (33) "Like I said, it is considered murder if you slept with somebody then that person } \\
\text { had one time thing with you and he goes and gets and he knows who you are, it is a } \\
\text { risk, it's a felony rap, it's a murder rap on you, you know?" (Los Angeles) }\end{array}$ & 44 & H \\
\hline & $\begin{array}{l}\text { (34) "For one thing, you know that I found out, there are cases of murder or } \\
\text { manslaughter..." (Los Angeles) }\end{array}$ & 39 & W \\
\hline
\end{tabular}




\section{Indirect disclosure}

While this study focused on explicit (that is, verbal) HIV disclosure, many respondents nevertheless reported indirect disclosure methods (that is, non-verbal) including leaving HIV medications visible to partners; listing HIV status when looking for sex partners on the internet; and displaying tattoos such as those with a "+" symbol.

\section{DISCUSSION}

Our findings provide evidence that disclosing one's HIV status to sexual partners is complicated and dependent on multiple and often competing emotional, situational, and legal factors; consequently few men in our study had a consistent pattern of disclosing. The themes identified suggest areas for future study and avenues for potential intervention, but also illustrate how complex promoting disclosure is likely to be among MSM. We conceptualise these themes as falling into four broad and related categories: (1) ethical obligations related to HIV (nobody's business, responsibility, fear of the law); (2) acceptance and adjustment to HIV positivity (denial, fearing rejection); (3) gauging risk and rationalisation (low viral load, type of sex); and (4) the context and meaning of sex (drug use, public sex, just sex, more than sex).

Our study points to a particularly salient role for the sense of responsibility around HIV transmission. Some participants rejected the idea of an obligation to inform sex partners of their potential exposure to HIV, while others clearly acknowledged such responsibility, either as a consequence of an internal sense of ethics or fear of the ramifications caused by not disclosing their HIV status. To the extent that most men, even in a group that we regarded as potential HIV transmitters, acknowledged an ethical responsibility to disclose, it may be possible to capitalise on this sense of obligation to encourage disclosure. Some men attributed their failure to disclose to being in denial about their HIV status or fearing rejection. Building these men's skills related to disclosure and modelling successful approaches to disclosure or role playing may help them to disclose more consistently. Indeed, data from a randomised controlled trial suggest that interventions to boost disclosure self efficacy may hold promise. ${ }^{17}$ Whether this can be accomplished during brief clinical encounters in an STI clinic or whether such interventions might be integrated into ongoing public health activities is uncertain. Men who seemed to reject any sense of responsibility pose a more difficult prevention challenge.

Another reason cited for not disclosing their HIV status among men in Seattle (but not Los Angeles) was having a low viral load and engaging in lower risk practices. Decisions not to disclose in lower risk situations were frequently based on what are likely accurate perceptions about transmission risks, such as the lower risk of transmitting to a negative partner during receptive anal $\operatorname{sex}^{18}$ and the decreased risk of transmission associated with a low viral load. ${ }^{19}$ However, some men acknowledged their use of information about factors that modify transmission risk served as rationalisations to avoid disclosing, and some were in conflict about whether this non-disclosure was acceptable when adopting lower risk behaviours. If disclosure is to be promoted in what are perceived to be lower risk situations, the likely accuracy of these men's perceptions will need to be acknowledged. Prevention messages will need to emphasise the uncertainty of some of the information about risk (that is, absolute risk associated with different sex acts), and the likely heterogeneity of transmission risk associated with a behaviour based on other factors (that is, HIV viral load, concurrent STI, circumcision, etc). An additional challenge in promoting disclosure in these situations is that disclosure does not always result in increased sexual safety, and some men could adopt more unsafe behaviours with willing partners if they no longer feel obliged to protect partners following disclosure.

It is of note that only men in Seattle stated they had a low risk of transmission because they had a low viral load and knew their viral load, suggesting in this city the HIV positive population may be more educated about HIV, have greater access to obtaining viral loads, or that more are in regular care than in Los Angeles. Given that the men from Seattle had a higher educational status and most were of white ethnicity, such men may have greater access to care, be getting more sophisticated care, or be absorbing more information about their HIV than the less educated, mostly ethnic minority men from Los Angeles in this study.

Another theme in which sophistication about HIV status was revealed was in choice of type of sex and belief that with less risky sex there was less of an obligation to disclose. This suggests "selective" or "strategic" positioning, a practice in which HIV positive men report opting to be receptive with HIV negative or HIV status unknown partners. ${ }^{20}$ There were MSM in this study who thought they could avoid disclosing by avoiding risky sex by either using condoms, having only receptive anal sex, no anal sex, or only oral sex. Some of the men who thought they were reducing the probability that they could transmit to a partner through less risky sex acts nevertheless acknowledged knowing that this did not guarantee absolute safety.

Many men identified the influence of the context in which sex occurs (for example, with drug use, in public venues, anonymously) on disclosure. Previous studies have associated use of drugs like methamphetamines with high risk sexual behaviour ${ }^{21-23}$ and our findings suggest that many HIV positive methamphetamine using MSM attribute their failure to disclose to their drug use, stating that under the influence they either forget or just don't care about disclosing. Therefore, drug abuse prevention and treatment or increased law enforcement may affect this sexual context by promoting increased disclosure and decreased sexual risk. Public sexual venues might be reorganised, regulated, or closed to decrease situations that facilitate high risk sex without disclosure. Finding ways to promote relationships among MSM that involve sex as more than "just sex" will prove challenging, but merits consideration.

Many respondents thought partners should ask about their HIV status, and some assumed that if a partner does not ask, he must also be positive. These men frequently expressed an expectation to be asked, or they won't tell. This "don't ask, don't tell" construct has been observed elsewhere ${ }^{24}$ and seems to be a reciprocally preserved construct as both positive and negative men avoid discussing HIV. Of note, a recent qualitative study found that HIV negative men fear rejection by HIV positive partners who want unprotected anal intercourse, and face many of the same barriers to disclosure and adopting safer sex behaviours that we observed in our study of HIV positive MSM. ${ }^{25}$ These complementary studies emphasise the need to promote disclosure as a shared responsibility that can be difficult for both HIV positive and HIV negative MSM.

One unexpected finding was that awareness of legal implications for lack of disclosure for transmission of HIV among MSM influenced some to disclose more often. Although the mantra in HIV prevention for many years has been that promoting fear is an ineffective prevention strategy, our findings suggest that if more people were aware that they could be prosecuted for infecting others with HIV, this might enhance a sense of responsibility and increase the likelihood that HIV positive MSM disclose to partners before sex. Clearly, more research is needed before these findings could 
be translated into any public campaign wishing to address HIV disclosure rates for MSM.

This study was not designed to capture a representative sample of HIV positive MSM, and the men interviewed were selected based on criteria that meant they were a high transmission risk regardless of their race or ethnicity. The themes and patterns around disclosure noted here are from men who acknowledge taking sexual risks or who have recently suffered the effects of such lapses in protective behaviour by having a recent STI. Therefore, HIV positive men who are not at STI clinics may have other patterns of disclosure and disclose more often. However, the men in this study are those who are likely to be spreading HIV in their communities by having exposed partners to HIV. Although these findings are limited because they are based on a specific and small sample of HIV positive MSM, they are illustrative of the men who should be the priorities of prevention programmes as they represent probable sources of transmission.

While we have focused on this unique population of likely "key transmitters" (given both their HIV status and recent STI), these findings may also be applicable to HIV negative men. Insofar as non-disclosure facilitates HIV transmission, our study suggests that there will continue to be new cases of STIs and HIV along the west coast of the United States, and presumably in other geographic areas, until more people talk about their HIV status with sex partners and make mutual decisions to act on that information in ways that prevent HIV transmission. Future studies should assess the feasibility and effectiveness of interventions designed to capitalise on MSM's sense of ethics and help them adjust to their HIV positivity, integrate disclosure into other risk reduction strategies that are sometimes seen as alternatives to disclosure, and attempt to alter the context and meaning of sex.

\section{ACKNOWLEDGEMENTS}

The authors wish to thank John Copeland, Mark Fleming, Michael Westrick, and Cielo Fernandez-Ortega, for interview support and study administration and the Los Angeles Gay and Lesbian Center and Los Angeles Shanti for advertising and interview space. This study was funded by the UARP Idea Award ID02-LA-023: "Developing Interventions for Men Who Have Sex Men with HIV and STDs in Los Angeles."

\section{Authors' affiliations \\ P M Gorbach, J T Galea, B Amani, A Shin, University of California, Los Angeles, CA, USA \\ C Celum, M R Golden, University of Washington, Seattle, WA, USA \\ P Kerndt, STD Program, Los Angeles County Department of Public Health, CA, USA}

\section{REFERENCES}

1 Centers for Disease Control and Prevention. Resurgent bacterial sexually transmitted disease among men who have sex with men-King County, Washington, 1997-1999. MMWR Morb Mortal Wkly Rep 1999;48:773-7.

2 Centers for Disease Control and Prevention. Increases in unsafe sex and rectal gonorrhea among men who have sex with men-San Francisco, California, 1994-1997. MMWR Morb Mortal Wkly Rep 1999:48:45-8.

3 Ciccarone DH, Kanouse DE, Collins RL, et al. Sex without disclosure of positive HIV serostatus in a US probability sample of persons receiving medical care for HIV infection. Am J Public Health 2003;93:949-54.

4 Janssen RS, Holtgrave DR, Valdiserri RO, et al. The serostatus approach to fighting the HIV epidemic: prevention strategies for infected individuals. Am J Public Health 2001;91:1019-24.

5 Centers for Disease Control. Advancing HIV prevention: new strategies for a changing epidemic. Morb Mortal Wkly Rep 2003;52:1-4.

6 Centers for Disease Control. Recommendations for incorporating human immunodeficiency virus (HIV) prevention into the medical care of persons living with HIV. Clin Infect Dis 2004;38:104-21.

7 Marks G, Crepaz N. HIV-positive men's sexual practices in the context of selfdisclosure of HIV status. J Acquir Immune Defic Syndr 2001;27:79-85.

8 Serovich JM, Mosack KE. Reasons for HIV disclosure or nondisclosure to casual sexual partners. AIDS Educ Prev 2003;15:70-80.

9 Reback CJ, Larkins S, Shoptaw S. Changes in the meaning of sexual risk behaviors among gay and bisexual male methamphetamine abusers before and after drug treatment. AIDS Behav 2004;8:87-98.

10 Zea MC, Reisen CA, Poppen PJ, et al. Asking and telling: communication about HIV status among Latino HIV-positive gay men. AIDS Behav 2003;7:143-52.

11 Wolitski RJ, Rietmeijer CA, Goldbaum GM, et al. HIV serostatus disclosure among gay and bisexual men in four American cities: general patterns and relation to sexual practices. AIDS Care 1998;10:599-610.

12 Wasserheit JN. HIV infection and other STDs: so close and yet so far. Sex Transm Dis 1999;26:549-50.

13 Galvin SR, Cohen MS. The role of sexually transmitted diseases in HIV transmission. Nat Rev Microbiol 2004:2:33-42.

14 Spradley JP. The ethnographic interview. New York: Holt, Rinehart, and Winston, Inc, 1979.

15 MacQueen MM, McLellan E, Kay K, et al. Codebook development for teambased qualitative analysis. Cultural Anthropology Methods 1988:10:31-6.

16 Miles MB, AM H. Qualitative data analysis: an expanded sourcebook. Thousand Oaks, CA: Sage Publications, 1994

17 Kalichman SC, Rompa D, Cage M, et al. Effectiveness of an intervention to reduce HIV transmission risks in HIV-positive people. Am J Prev Med 2001;21:84-92.

18 Varghese B, Maher JE, Peterman TA, et al. Reducing the risk of sexual HIV transmission: quantifying the per-act risk for HIV on the basis of choice of partner, sex act, and condom use. Sex Transm Dis 2002;29:38-43.

19 Quinn TC, Wawer MJ, Sewankambo N, et al. Viral load and heterosexual transmission of human immunodeficiency virus type 1. Rakai Project Study Group. N Engl J Med 2000;342:921-9.

20 Van de Ven P, Kippax S, Crawford J, et al. In a minority of gay men, sexual risk practice indicates strategic positioning for perceived risk reduction rather than unbridled sex. AIDS Care 2002; 14:471-80.

21 Molitor F, Traux SR, Ruiz JD, et al. Association of methamphetamine use during sex with risky sexual behaviors and HIV infection among non-injection drug users. Western J Med 1998;168:93-7.

22 Purcell DW, Parsons JT, Halkitis PN, et al. Substance use and sexual transmission risk behavior of HIV-positive men who have sex with men. J Substance Abuse 2001;13:185-200.

23 Reback CJ, CE. G. HIV risk behaviors of gay and bisexual male methamphetamine users contacted through street outreach. J Drug Issues 1999;29:155-66

24 Klitzman R. In:, Klitzman R, Bayer R. Mortal secrets: truth and lies in the age of AIDS. Baltimore: Johns Hopkins University Press, 2003:218.

25 Sheon N, GM. C. Ambivalent tales of HIV disclosure in San Francisco. Soc Sci Med 2004;58:2105-18. 